\title{
Deposition in boreal forests in relation to type, size, number and placement of collectors
}

\author{
M. Starr · L. Ukonmaanaho · P.K. Sibley • \\ P.W. Hazlett · A.M. Gordon
}

Received: 23 June 2005 / Accepted: 11 April 2006 / Published online: 28 November 2006

(C) Springer Science + Business Media B.V. 2006

\begin{abstract}
Open precipitation and throughfall was collected at a Norway spruce stand in Finland using funnel-type collectors and at a black spruce stand in Canada using trough-type collectors. The presence or absence of a rim on the funnel, funnel diameter $(9,14$ and $20 \mathrm{~cm}$ ) and length of sampling period (1,2 and 4 weeks) on monthly values were evaluated at the Norway spruce stand, and the number of collectors required for defined levels of accuracy and precision of throughfall loads to be reached and the influence of the spatial arrangement of collectors on solute concentrations was studied at both stands. The presence of a rim had no significant effect on open precipitation and throughfall amounts, but did on throughfall DOC, $\mathrm{Ca}^{2+}, \mathrm{Mg}^{2+}$, $\mathrm{K}^{+}, \mathrm{Na}^{+}$and $\mathrm{Cl}^{-}$ion loads. Deposition loads increased with decreasing funnel diameter; for open precipita-
\end{abstract}

M. Starr $(\bowtie)$

Department of Forest Ecology, University of Helsinki, P.O.

27, FI-00014 University of Helsinki, Finland

e-mail: mike.starr@helsinki.fi

\section{Ukonmaanaho}

Finnish Forest Research Institute, Vantaa Research Centre, P.O. Box 18, FI-01301 Vantaa, Finland

P.K. Sibley · Gordon A.M.

Department of Environmental Biology, University of

Guelph, Guelph, Ontario, NIG 2W1, Canada

P.W. Hazlett

Natural Resources Canada, Canadian Forest Service, 1219

Queen St. E., Sault Ste. Marie, Ontario, P6A 5M7, Canada tion, this was due to increased catch efficiency while for throughfall the increase was attributed to canopy interaction and leaching of litter trapped in the collectors. Calculated monthly $\mathrm{H}^{+}$loads decreased and those for all other constituents increased with collection period length. Using 15 collectors at the Norway spruce stand would allow throughfall loads to be determined to within $20 \%$ of the true mean weekly value with a confidence level of $95 \%$ for most solutes, but not for $\mathrm{NH}_{4}{ }^{+}-\mathrm{N}, \mathrm{NO}_{3}{ }^{-}-\mathrm{N}, \mathrm{Mg}^{2+}$ and $\mathrm{SO}_{4}{ }^{2-}-\mathrm{S}$. Using 15 trough collectors, the same confidence level at the more heterogeneous black spruce stand would only be achieved for $\mathrm{H}^{+}, \mathrm{Cl}^{-}$, DOC and $\mathrm{SO}_{4}{ }^{2-}-\mathrm{S}$ loads. In both stands, non-plantation stands, using either random or systematic placements of throughfall collectors gave similar results.

Keywords Black spruce · ELRA · ICP-Forests · Norway spruce · Nutrient loads · Precipitation · Sampling accuracy and precision · Throughfall

\section{Introduction}

In nutrient cycling studies and research investigating the effects of atmospheric pollution on forest ecosystems it is necessary to measure the deposition of substances to the ecosystem from the atmosphere. This deposition occurs commensurately with rainfall and/or snowfall (termed wet deposition), and by the sedimentation of suspended particles between rainfall events (termed dry deposition). In areas affected by fog, 
occult deposition is also important. Deposition collectors left permanently open collect both wet and dry deposition. Besides the sedimentation of suspended particles to open ground and forest, the forest canopy, particularly those of coniferous forests, is effective in filtering and trapping additional fine particles and aerosols from the air (e.g. Parker, 1983; Hyvärinen, 1990). The washoff of these trapped particles greatly adds to the total deposition of substances to the forest ecosystem.

Precipitation passing through the canopy is known to be modified such that both the quality and quantity of precipitation reaching the forest floor (throughfall) differs widely from that of precipitation collected in open areas. Because of interception and subsequent evaporation, throughfall quantities are usually $60-90 \%$ of precipitation collected in the open (Parker, 1983; Kimmins, 2004). Typically for boreal forests, which are often nitrogen $(\mathrm{N})$ limited, the concentrations of nitrate $\left(\mathrm{NO}_{3}{ }^{-}\right)$and ammonium $\left(\mathrm{NH}_{4}{ }^{+}\right)$in throughfall are less than that in open precipitation as a result of uptake by the foliage or by resident micro-flora (e.g. Hyvärinen, 1990; Piirainen et al., 1998; Ukonmaanaho and Starr, 2002; Morris et al., 2003). However, Gordon et al. (2000) found nitrogen enrichment of throughfall collected under black, white and red spruce canopies. The amounts of base cations potassium $\left(\mathrm{K}^{+}\right)$, calcium $\left(\mathrm{Ca}^{2+}\right)$, and magnesium $\left(\mathrm{Mg}^{2+}\right)$ tend to be higher in throughfall due to the wash-off of dry deposition from the canopy and/or leaching of elements from within the foliage. Throughfall enrichment in boreal forests in Finland has been shown to be $65 \%$ or more for $\mathrm{Ca}^{2+}$ and $\mathrm{Mg}^{2+}$ and up to $97 \%$ for $\mathrm{K}^{+}$(Ukonmaanaho and Starr, 2002). In a Canadian black spruce forest, throughfall enrichment of $\mathrm{Ca}^{2+}, \mathrm{Mg}^{2+}$ and $\mathrm{K}^{+}$was $70 \%, 115 \%$ and 190\%, respectively (Morris et al., 2003). The leaching of base cations from within foliage tissue alone can account for $10-80 \%$ of the total return of base cations to the forest floor (e.g. Tukey, 1970; Cole and Rapp, 1981). By comparing the loads of conservative elements, e.g. sodium $\left(\mathrm{Na}^{+}\right)$, in open precipitation and throughfall, it is possible to estimate the atmospheric total deposition component of throughfall (Bredemeier, 1988).

The degree of interaction between wet and dry deposition and the canopy varies not only among elements but also with stand composition and structure and the characteristics of precipitation (quality, duration and intensity), all of which exhibit high spatial and temporal variability. In order to provide a satisfactory estimate of the flux of elements to the forest floor, this variability should be considered when designing throughfall collection. Factors affecting precipitation and deposition catch efficiency include: height of the collector above the ground and below the canopy, area of the collector orifice, surface area of collector exposed to the air in the case of funnel-type collectors, area of the opening from which evaporation of the entrapped sample may take place, and the shape and degree of shielding of the collector (Mahendrappa and Kingston, 1982; Kostelnik et al., 1989; Puckett, 1991; Førland et al., 1996; Thimonier, 1998; Dingman, 2002). For accurate and precise areal estimates of deposition loads, the number and spatial arrangement of collectors and the collection period are also important considerations.

Ideally, throughfall collectors should be made of inert material, designed such that the collector is not affected by wind and splashing, and the precipitation collected is not subject to evaporation losses (Reynolds and Neal, 1991; Førland et al., 1996) if left in the collector for extended periods of time. Throughfall collectors in most studies are bulk collectors, i.e. permanently open collectors that collect both wet and dry deposition. Peripheral shielding and the shape and size of the throughfall collector have a strong influence on the amount of dry and wet deposition collected. Trough collectors are considered to collect more representative samples than funnel collectors, as troughs integrate over a larger range of canopy conditions and structure (e.g. Kostelnik et al., 1989; Draaijers et al., 1996). For both types of collectors, there are several sources of error that can affect the precision and accuracy of collector volumes and solute concentrations (Reynolds and Neal, 1991).

Wind is the main source of error in precipitation measurements (Førland et al., 1996; Dingman, 2002), and peripheral shielding of the collector can be used to reduce this error. However, wind speed is usually less in forests compared to open areas and windshields are not commonly used. Nevertheless, the presence of a rim around the edge of the funnel effectively acts as a windshield, enabling drops and particles that would otherwise blow over the orifice to be collected while at the same time reducing splash-out losses. Evaporation loss after collection is another important source of error affecting both the quantity and quality of throughfall and open precipitation (Førland et al., 1996). Such losses can be reduced by using small openings connecting the funnel and the sample collector and by using 
shorter intervals between collection times. The quality of the throughfall sample can also be affected by the leaching of solutes from litter falling into the collectors (Ukonmaanaho and Starr, 2001). This effect can be minimized by using a plastic mesh screen to prevent litter entry into the collected sample and through periodic cleaning of the screen.

Numerous studies have evaluated the effects of collector design and throughfall variability in relation to the number of collectors and sampling interval on throughfall quantity and quality (e.g. Kostelnik et al., 1989; Puckett, 1991; Reynolds and Neal, 1991; Draaijers et al., Thimonier, 1998; Bleeker et al., 2003). However, few studies have examined the effect of the field arrangement of collectors.

The objectives of this study were: to examine the influence of funnel diameter and presence of a rim on throughfall loads and compare with those collected in the open, to determine if the length of the collection period affected throughfall loads, to determine the number of funnel and trough-type collectors required to reach certain levels of accuracy and precision for throughfall loads, and examine the influence of the spatial arrangement of funnel and trough-type collectors on throughfall quality. The study was carried out at two boreal spruce stands, one a Norway spruce (Picea abies) stand in Finland using funnel-type collectors and the other, a black spruce (Picea mariana) stand in Canada using trough-type collectors. The study al- lows comparison of throughfall collection in different regions of the boreal zone having different tree species composition and stand characteristics as well as the effect of collector design and layout.

\section{Material and methods}

\subsection{Study stands}

In order to reduce variability, selection of the two study stands was based on several criteria: they should represent the dominant tree species in the respective regions, be composed of a single species, and be as uniform as possible with regard to tree size, stand density and evenness.

\subsubsection{Norway spruce stand, Finland}

The 63-year-old Norway spruce stand was located at Kasiniemi in southern Finland (Table 1). The most common coniferous tree species in Finland are Scots pine (Pinus sylvestris) and Norway spruce, with the latter occupying approximately $34 \%$ of all forested lands (Finnish Statistical Yearbook of Forestry, 2003). According to the Finnish site classification scheme (Cajander, 1949; Mikola 1982), the site is classified as an Oxalis-Myrtillus type (OMT), meaning that it is a relatively nutrient-rich and moist site with good forest production (mean annual growth $\sim 10 \mathrm{~m}^{3} \mathrm{ha}^{-1} \mathrm{yr}^{-1}$ ).

Table 1 Stand and climate characteristics for the Norway spruce stand (Finland) and the black spruce stand (Canada)

\begin{tabular}{|c|c|c|}
\hline & Norway spruce (Finland) ${ }^{a}$ & Black spruce (Canada) \\
\hline Latitude & $61^{\circ} 25^{\prime} \mathrm{N}$ & $49^{\circ} 38^{\prime} \mathrm{N}$ \\
\hline Longitude & $24^{\circ} 55^{\prime} \mathrm{E}$ & $81^{\circ} 00^{\prime} \mathrm{W}$ \\
\hline Elevation, $\mathrm{m}$ a.s.l. & 135 & 286 \\
\hline Mean long-term ${ }^{b}$ temperature, ${ }^{\circ} \mathrm{C}$ & 4.3 & $0.6^{c}$ \\
\hline Mean long-term ${ }^{b}$ annual precipitation, mm & 575 & $880^{c}$ \\
\hline Mean temperature in sampling year, ${ }^{\circ} \mathrm{C}$ & 4.2 & $1.3^{d}$ \\
\hline Precipitation in sampling year, mm & 662 & $902^{d}$ \\
\hline Precipitation in sampling period, $\mathrm{mm}$ & 318 & 256 \\
\hline Stem volume, $\mathrm{m}^{3} \mathrm{ha}^{-1}$ & 340 & 171 \\
\hline Breast height diameter (dbh), $\mathrm{cm}$ & 27.5 & 14.3 \\
\hline Stocking density, stems ha ${ }^{-1}$ & 467 & 1670 \\
\hline Canopy projection, $\%$ & 57 & $>60$ \\
\hline
\end{tabular}

${ }^{a}$ Leteensuo, $61^{\circ} 04^{\prime} \mathrm{N} 24^{\circ} 14^{\prime} \mathrm{E}, 88 \mathrm{~m}$ a.s.1. (Drebs et al., 2002).

${ }^{b}$ 1971-2000.

${ }^{c}$ Cochrane, Ontario $49^{\circ} 04^{\prime} \mathrm{N}, 81^{\circ} 01^{\prime} \mathrm{W}, 275 \mathrm{~m}$ a.s.1., (Environment Canada, 2004).

${ }^{d}$ Bonner Lake, Ontario $49^{\circ} 22^{\prime} \mathrm{N}, 82^{\circ} 07^{\prime} \mathrm{W}, 245 \mathrm{~m}$ a.s.1., (Environment Canada, 2004). 
The soil is podzolic and developed in glacial till deposits with a mor surface organic layer. Norway spruce seedlings were planted in 1933-34, replacing the original birch (Betula pubescens) stand. The stand has been thinned 3 times (last time in 1991) and fertilized twice (in the 1970s and 1980s) resulting in a relatively evenly sized and spaced stand. There were some gaps in the canopy where snags, the result of snow damage, had been removed or had fallen to the ground. These gaps were avoided when selecting sampling points for positioning the throughfall collectors.

The characteristics of the study stand and the mean annual temperature and precipitation at the nearby official meteorological station in Leteensuo are presented in Table 1. Out of the 18 weeks covered by the study period (June-September 1998) there was only one week when there was no rainfall. Precipitation over the study period was $19 \%$ greater than the long-term (19712000) average.

\subsubsection{Black spruce stand, Canada}

The black spruce stand was located on the shoreline of a small lake in the Clay Belt region of the north-eastern Ontario (Table 1) and forms part of the Esker Lakes Research Area (ELRA). The soil is podzolic and developed on a glacial esker with variable texture throughout the top $1 \mathrm{~m}$. Typical for the Clay Belt region, the soil has high clay content and is relatively fertile. The 95year-old study stand is unmanaged, of fire-origin, and dominated by black spruce ( $89 \%$ of total basal area). There are standing and fallen dead trees in the stand resulting from self-thinning. This even-aged stand represents a black spruce-feathermoss site, Operational Group 5 in the Ontario Forest Ecosystem Classification System (Jones et al., 1983). Other tree species present are: eastern white cedar (Thuja occidentalis), tamarack (Larix laricina), white spruce (Picea glauca), balsam fir (Abies balsamea) and speckled alder (Alnus incana), all of which were more common along the immediate shoreline at the site.

Stand characteristics and climate data from nearby meteorological stations are presented in Table 1. Climatic measurements during the study period (AugustOctober 2002) for the black spruce stand are taken from the meteorological station at Bonner Lake, Ontario and long-term average values from Cochrane, Ontario (Environment Canada, 2004). Precipitation over the study period was 7\% lower than the long-term (1971-2000) average value. Precipitation during August to October usually contributes $31 \%$ of annual precipitation.

\subsection{Collector designs and sampling procedure}

We studied funnel- and trough-type throughfall collectors (Fig. 1, Table 2). The funnel collectors were used in the Norway spruce stand and the trough collectors in the black spruce stand. The four funnel collectors differed in their diameter, whether or not they had a rim and the slope of funnel wall. Two different sized trough collectors were used, but the limited number of samples collected did not allow statistical testing of collection area effects and only experimental layout effects are considered in this paper. All the collectors were constructed from polyethylene plastic.

The three diameter sizes of funnel in our study correspond with those that have been used throughout Europe in the UN-ECE ICP-Forest monitoring programme (ICP Forest Manual, 1998). The collection surface of each funnel was positioned $1.5 \mathrm{~m}$ above ground and the sample collected in a plastic bag placed inside the black PVC tube supporting the funnel. The neck of the funnel was fitted with a plastic mesh to prevent litter falling into the plastic bag. Upon retrieving the samples, the bags were weighed and the value

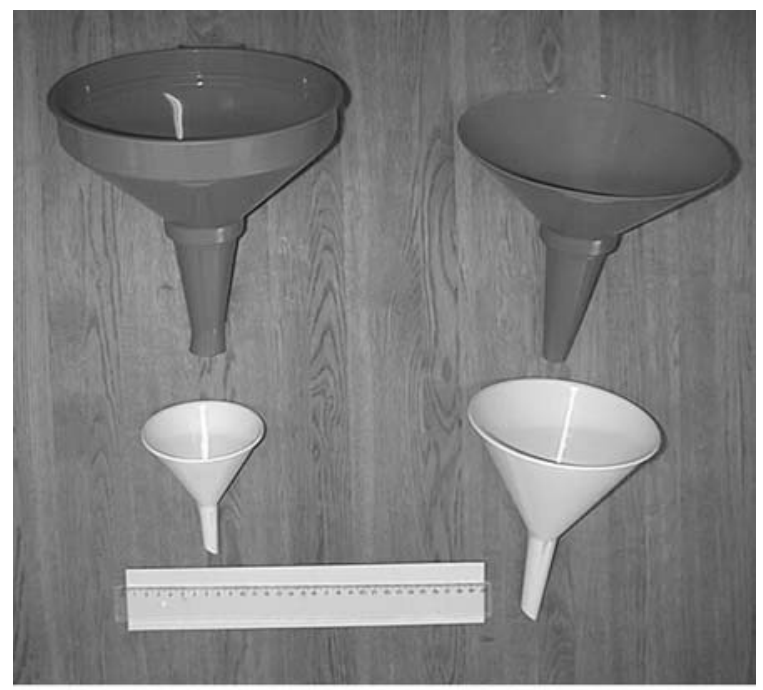

(a)

Fig. 1 a) Photograph showing the four types of funnel used in the Norway spruce stand in Finland. Clockwise from the top left: type1, type 2, type 3 and type 4 (see Table I for dimensions). b) a throughfall collector in the Norway spruce stand, Finland, and c) a trough collector in the black spruce stand, Canada. (continued) 


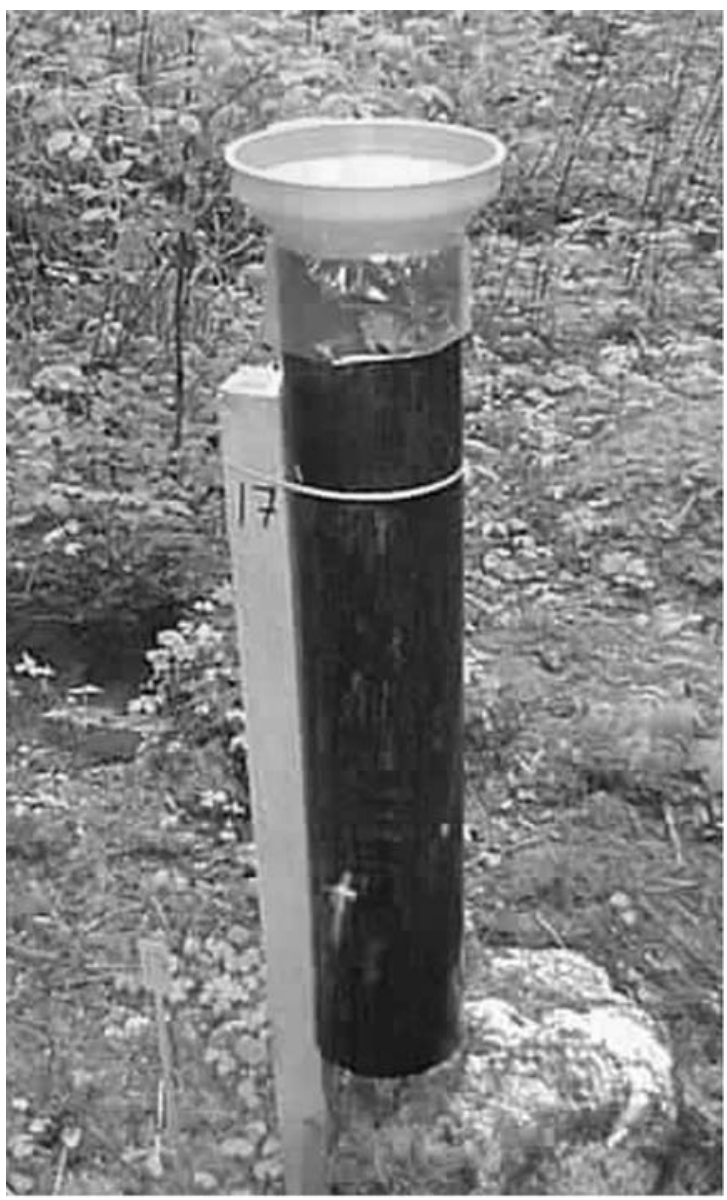

(b)

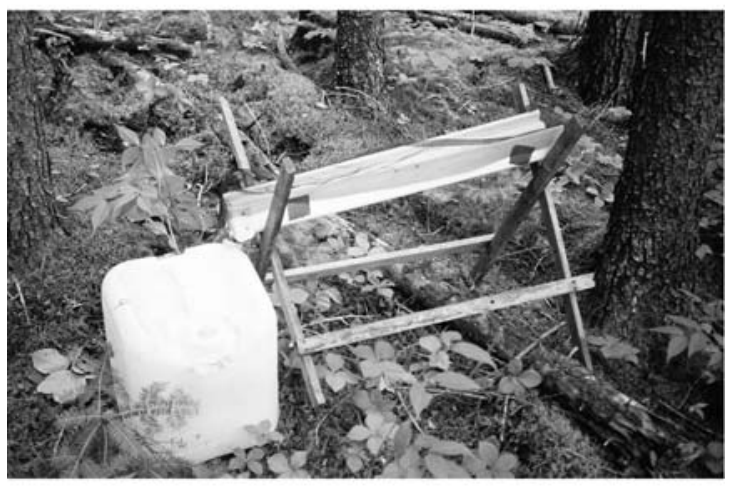

(c)

Fig. 1 (Continued)

recorded (minus weight of bag). The sample was then transferred to a polyethylene bottle and placed in a styrene box, kept cool with freezing blocks and transported to the laboratory within one day. Following each sample collection, the funnels and mesh were rinsed with distilled-deionised water and a fitted with a new plastic bag. Samples were collected weekly between June 1 and October 5 1998. As there was no rainfall during the $14^{\text {th }}$ week (1-7 September), the number of weeks with samples was 17 .

In order to determine whether the length of the collection period had an effect on monthly deposition values we collected throughfall samples for two and four week periods in addition to the weekly samples described above. Two additional type 1 funnels were installed within $1 \mathrm{~m}$ of four of the original type 1 funnels (selected randomly). One of the pair of additional collectors was emptied at the end of every 2 nd week and the other at the end of every 4th week. On the occasion of the 4th week, the collector that had been used to collect the two fortnightly samples became the collector for the following 4-week collection and the collector that had been used to collect the 4-week sample became the collector for the two fortnightly samples. Otherwise the samples were treated the same as described above.

The trough collectors were covered with nylon mesh to prevent the entry of litter and inclined at about $30^{\circ}$ so as to allow drainage into either a 10 or $20 \mathrm{~L}$ polyethylene container (Table 2, Fig. 1). The offshore collectors were attached to $90 \times 80 \mathrm{~cm}$ wooden rafts anchored in place by a rope tied to shoreline trees. Throughfall sampling commenced July 292002 and samples were collected 3 times in August, and once in September and October. The volume of each throughfall sample was recorded in the field by weighing the total sample and a $250 \mathrm{ml}$ sub-sample was placed in a polyethylene bottle for freezing until analysis. The troughs and mesh were rinsed with distilled-deionised water after sampling.

\subsection{Experimental design}

\subsubsection{Norway spruce stand, Finland}

The position, height, breast height diameter (dbh) and canopy projection of every tree in an area approximately $70 \times 130 \mathrm{~m}$ of the most uniform part of the stand and as far from the forest road as possible was measured using standard mensuration procedures. A $10 \times 10 \mathrm{~m}$ grid was placed over the resulting tree map such that none of 72 intersections within a $60 \times$ $110 \mathrm{~m}$ block fell on a tree stem. The block of 72 points was then divided into four equal sized sub-blocks of 
Table 2 Characteristics of the funnel and trough collectors used in the study

\begin{tabular}{lllll}
\hline Collector type & Diameter or size, cm & Collection area, $\mathrm{cm}^{2}$ & Rim height, cm & Funnel slope $^{\circ}$ \\
\hline${\text { Funnel } 1^{a}}^{a}$ & 20 & 308 & 2 & 45 \\
Funnel 2 & 20 & 308 & 0 & 45 \\
Funnel 3 & 14 & 154 & 0 & 64 \\
Funnel 4 & 9 & 64 & 0 & 64 \\
Trough $1^{c}$ & $10 \times 75$ & 750 & 6 & - \\
Trough 2 & $12 \times 77$ & 924 & 10 & - \\
\hline
\end{tabular}

${ }^{a}$ Used in the Finnish UN-ECE ICP Integrated Monitoring programme (Ukonmaanaho and Starr, 1995).

${ }^{b}$ Used in the Finnish UN-ECE ICP Forest/EU, Level II programme (Lindroos et al., 1999).

${ }^{c}$ Used by e.g. Morris et al. (2003), Gordon et al. (2000).

18 points and the positions of these intersections located in the field. A funnel type was randomly allocated at 16 of the 18 points in each of the four sub-blocks; the 16 site points being the least affected by a gap or tree species other than Norway spruce. To increase the amount of sample collected using the $9 \mathrm{~cm}$ diameter funnels we used two at each of the sampling stations, the throughfall from the two collectors draining into the same sample collection bag. Thus, there were 16 replicates of each type of funnel, giving a total of 64 sampling stations in the experiment.

To determine if the spatial arrangement of collectors had an effect on throughfall we selected 12 funnels in five spatial arrangements: two rectangular grids $(10 \times$ $10 \mathrm{~m}$ and $20 \times 20 \mathrm{~m}$ spacing), a square, a row, and a random set (Fig. 2). From the entire dataset for each week and for each spatial arrangement a collector was chosen at random. If a set of funnels for each arrangement could not be formed by including the selected funnel somewhere in the arrangement, then another funnel was randomly selected. This procedure was repeated three times, producing three sets of funnels for each spatial arrangement.

Two funnels of each type (total of 8 funnels) were also located in an open area $1 \mathrm{~km}$ away from the throughfall study stand. The funnels were randomly allocated to positions at the intersections of a $3 \times 3 \mathrm{~m}$ grid. Sampling was otherwise carried out as described for throughfall collectors.

\subsubsection{Black spruce stand, Canada}

The troughs were set out in a $16 \times 36 \mathrm{~m}$ study area. Fifteen trough collectors were arranged in each of two
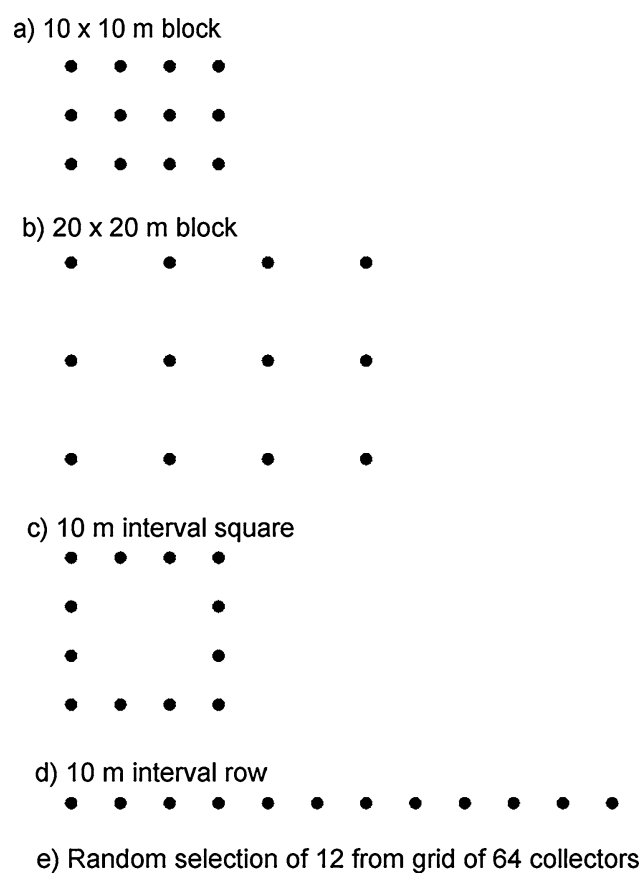

Fig. 2 Placement arrangements of throughfall funnel collectors tested in the Norway spruce stand, Finland

layouts: systematic and random (Fig. 3). In the systematic design, five collectors were placed at $7.5 \mathrm{~m}$ intervals along three lines parallel to the shore line. The collectors in the first line were floating approximately $0.5 \mathrm{~m}$ offshore. The second and third lines were located $5 \mathrm{~m}$ and $15 \mathrm{~m}$ distance upslope from the shoreline. In the random design, six collectors were positioned randomly either side of the second line. In addition, one trough from each of the three lines of systematically placed collectors was randomly selected on each sampling occasion and included in the results for the random design. 


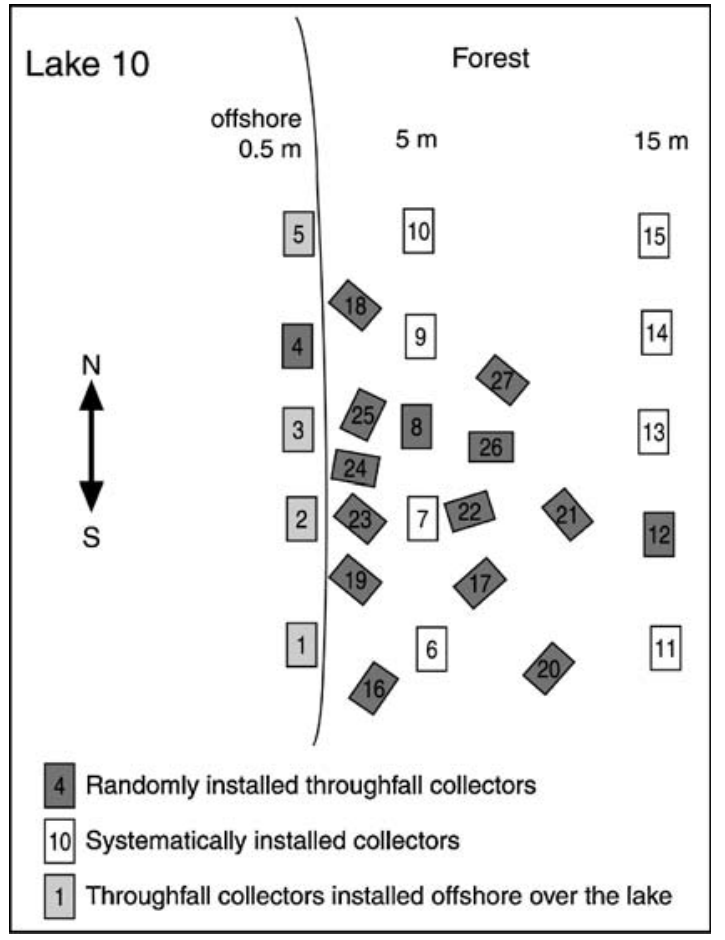

Fig. 3 Trough throughfall collector placement used in the black spruce stand, Canada

\subsection{Chemical analysis}

At both stands, the amount of water $(\mathrm{mm})$ and concentrations of cations $\left(\mathrm{Ca}^{2+}, \mathrm{Mg}^{2+}, \mathrm{K}^{+}, \mathrm{NH}_{4}^{+}-\mathrm{N}\right)$ and anions $\left(\mathrm{SO}_{4}{ }^{2-}-\mathrm{S}, \mathrm{Cl}^{-}, \mathrm{NO}_{3}-\mathrm{N}\right)$, total $\mathrm{N}$, dissolved organic carbon (DOC) and hydrogen $\left(\mathrm{H}^{+}\right)$ions (calculated from $\mathrm{pH}$ ) were determined. $\mathrm{Na}^{+}$ion concentrations were only determined for the Norway spruce stand.

\subsubsection{Norway spruce stand, Finland}

Collected samples were stored in dark and cool $\left(+4^{\circ} \mathrm{C}\right)$ conditions until analysis could be undertaken. The samples were filtered through a $0.45 \mu \mathrm{m}$ membrane filter and, depending on sample volume available, sub-samples for analysis were taken in the following order of priority: metal cations by inductively coupled plasma mass spectrometry, anions by ion chromatography, total $\mathrm{N}$ and $\mathrm{NH}_{4}{ }^{+}-\mathrm{N}$ by flow injection analysis, DOC using a Shimadzu TOC-5000 analyzer, and $\mathrm{pH}$ by electrode and meter.

\subsubsection{Black spruce stand, Canada}

The frozen samples were thawed before analysis. Conductivity and $\mathrm{pH}$ were determined first using a $\mathrm{pH} /$ conductivity meter after which the samples were filtered through a Fisherbrand Filter paper, P5 (particle retention 5-10 $\mu \mathrm{m}$ ). Anion concentrations were analyzed using ion chromatography. DOC, total $\mathrm{N}$ and $\mathrm{NH}_{4}{ }^{+}-\mathrm{N}$ were analyzed using a Technicon Autoanalyser II System, metal cation concentrations were determined using a Varian Spectra AA-3000 Atomic Absorption Spectrometer.

\subsection{Statistical analysis}

Throughfall and open precipitation deposition loads $\left(\mathrm{mg} \mathrm{m}^{-2}\right)$ for each collector and each sampling period were calculated as the product of concentration $(\mathrm{mg}$ $\mathrm{L}^{-1}$ ) and the amount of throughfall $(\mathrm{mm})$.

Differences in median throughfall loads between the four funnel types were tested using the Kruskal-Wallis non-parametric one-way analysis of variance. We used non-parametric statistics as the data were not normally distributed. If a significant $(p<0.05)$ difference in median values between funnel types was indicated, a multiple comparison test (Dunn's) was performed to determine which particular funnel types differed from each other. We used the same procedure to test for differences in concentrations between the spatial arrangement of collectors (between the five arrangements of funnels in the Norway spruce stand and between the systematic and random spatial arrangements of troughs in the black spruce stand). GraphPad Prism version 3.02 for Windows (GraphPad Software) was used to perform the statistical analysis.

To calculate how many collectors are needed for mean values to be within a certain range of the true population mean (accuracy) with a 95\% level of confidence (precision), we used the following equation:

$n=\left(t_{0.05} \cdot c v / c\right)^{2}$

where $t_{0.05}$ is the Student's $t$ value at the $95 \%$ level of confidence $\left(t_{0.05}=1.96\right), \mathrm{cv}$ is the coefficient of variation as a percentage, and $c$ is the desired percentage value of the true population mean. We calculated $n$ for values of $c$ set at 5\%,10\% and 20\%. Kostelnik et al. (1989) showed that Equation 1 is valid for small, nonnormally distributed populations (as in this study), but 
we logarithmically $\left(\log _{10}(x+1)\right)$ transformed the data to improve normality before applying the equation.

\section{Results and discussion}

\subsection{Differences between funnel types}

Only the funnel data were tested for the effects of collector diameter and presence of rim. The median open precipitation and throughfall collection volumes and deposition loads for each of the four funnel types are presented in Table 3 . The distribution of collection amounts and deposition loads were positively skewed for each funnel type. For open precipitation, the coefficient of variation (cv) was greatest for $\mathrm{H}^{+}$ions $(151 \%$, funnel type 4) and in throughfall for $\mathrm{Na}^{+}(234 \%$, funnel type 1). The lowest $\mathrm{cv}$ value was for DOC in open precipitation (42\%, funnel type 3 ) and for total $\mathrm{N}$ in throughfall (79\%, funnel type 3 ). Regardless of funnel-type, median throughfall values were less and deposition loads greater compared to open precipitation except for total $\mathrm{N}, \mathrm{NH}_{4}{ }^{+}-\mathrm{N}$ and $\mathrm{SO}_{4}{ }^{2-}-\mathrm{S}$, which showed little difference, and for $\mathrm{H}^{+}$ions and $\mathrm{NO}_{3}{ }^{-}-\mathrm{N}$, which were lower. These differences are in agreement with previously documented effects of canopy interaction with precipitation in boreal coniferous forests (e.g. Ukonmaanaho and Starr, 2002).

The effect of the rim on precipitation amount and quality was evaluated by comparing funnel type 1 and 2 results. While these funnels have the same sized opening, funnel type 1 has a rim but funnel type 2 does not (Table 2). The volume of precipitation collected in both the open and under the canopy did not significantly differ between these funnel types, although weekly median amounts collected in the open with type 1 funnels were always the same or greater than the amounts collected with funnel type 2 . The presence of the rim therefore had no significant effect on collector catch efficiency. However, median throughfall loads of DOC, mineral cations and $\mathrm{Cl}^{-}$ions were greater with funnel type 1 than funnel type 2 , and the differences were significant $(p<0.05$, Table 3$)$. Significant differences in throughfall concentrations for all solutes except $\mathrm{H}^{+}$ and inorganic forms of $\mathrm{N}$ were found between funnel types 1 and 2, but there were no such significant differences for open precipitation (concentration data not presented). These results suggest that while the rim had no effect on the volume of wet precipitation collected (catch efficiency) it did affect the amount of throughfall dry deposition. It would appear that the rim prevented dry deposition and fine litterfall material from being blown out of the funnel. This entrapped material would be washed or leached into the throughfall sample by subsequent rainfall, resulting in the higher solute concentrations and loads observed.

A number of processes can reduce the catch efficiency of precipitation, including evaporation of water adhering to the collector wall (wetting loss error), splash-out error, and failure to capture small drops due to air turbulence above the collector orifice induced by the collector itself (wind error) (Førland et al., 1996; Dingman, 2002). All three sources of error also affect the deposition loads. Open precipitation collection was also found to increase with decreasing funnel size in a Dutch study (Erisman et al., 2003), where the authors suggested that this was due to the creation of a vacuum in funnels having a large collection area by high winds accompanying rain showers. Increased deposition loads related to wetting loss errors are also the result of changes (increases) in solute concentrations; splash-out error and wind error do not affect solute concentrations and differences in loads are only due to differences in catch deficiencies.

The effect of catch area (funnel diameter in our study) is indicated by the differences between funnel types 2 (largest), 3 and 4 (smallest). The amount of precipitation collected in the open tended to increase with decreasing funnel diameter. The median amount of open precipitation collected with funnel type 4 was more than double that collected with funnel type 2 and the difference was significant $(p<0.05)$ (Table 3$)$. Funnel size did not, however, have a significant effect on throughfall quantities. Thus, the sources of precipitation catch error described above are less of a problem for throughfall, which can be attributed to the reduced wind speed and velocity of falling rain drops in forests.

Solute loads in throughfall and particularly in open precipitation tended to increase with decreasing funnel size. The differences between funnel types 2 and 4 were significant $(p<0.05)$ for most solutes (Table 3 ). Median open precipitation loads measured with funnel type 4 were two to three times those measured with funnel type 2 . While there were no significant differences in solute concentrations between the funnels of different size in the open, there were in throughfall concentrations (data not shown). Thus, while the differences in solute loads with funnel size in the open 


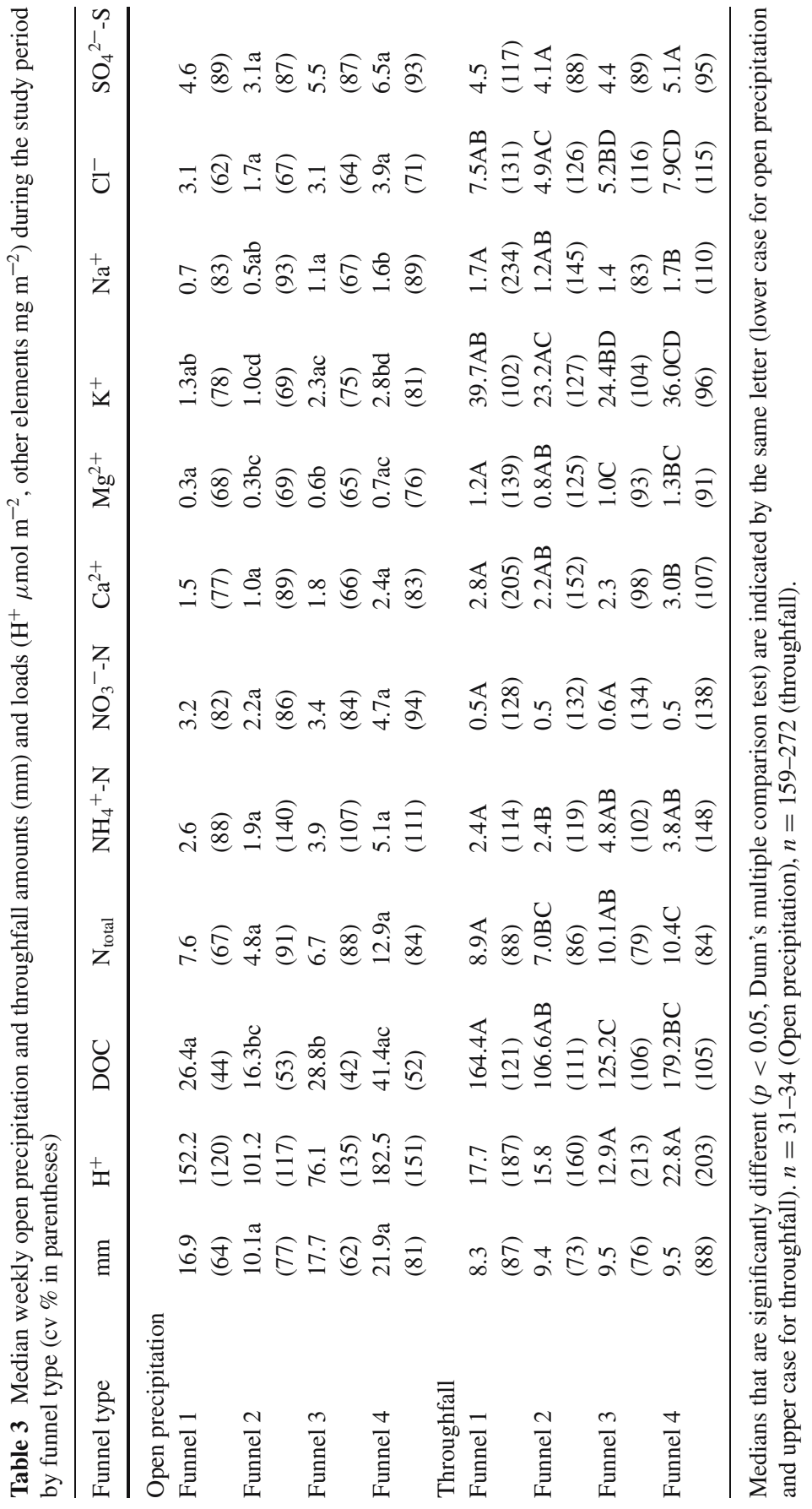


can be attributed to differences in the amount of precipitation collected, the differences in throughfall solute loads must be due to differences in solute concentrations. As discussed earlier, throughfall quality, unlike open precipitation, is strongly affected by interaction (desorption or adsorption) with the canopy and litterfall and debris from the canopy trapped in the throughfall collector (Ukonmaanaho and Starr, 2001). Canopy interaction effects would be the same regardless of funnel size but funnel size may have an effect on the amount of trapped litterfall and thus throughfall quality. Our results therefore indicate that smaller-sized funnels trap relatively more litterfall than larger-sized funnels and thus bias the throughfall deposition loads.

\subsection{Effect of collection period}

The calculated monthly throughfall volume and deposition loads for different collection periods (i.e. sum of 4 weekly samples, sum of 2 fortnightly samples, and the actual four week sample) are presented in Fig. 4. With only four monthly values, reliable statistical testing could not be made. However, consistent trends related to the length of the collection period were indicated. $\mathrm{H}^{+}$loads decreased and those for all other constituents increased with collection period
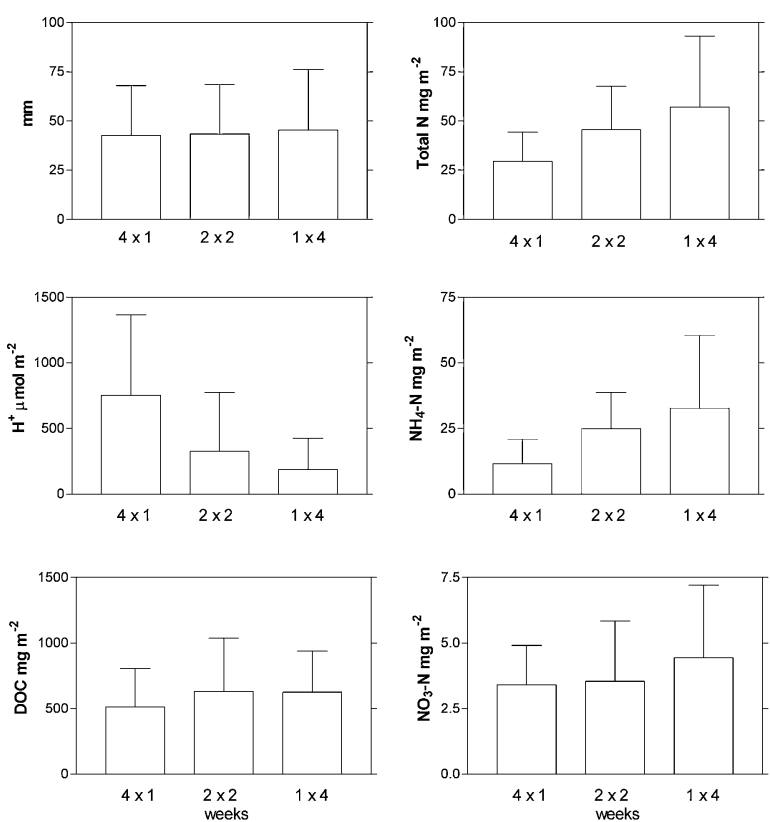

Fig. 4 Mean (and standard deviation, $n=4$ ) of monthly throughfall amounts and deposition loads calculated from different collection periods $(4 \times 1=$ sum of 4 weekly values, $2 \times 2=$ sum length. Samples collected over the 4-week period were observed to be yellow coloured compared to samples collected over shorter periods, also indicating that changes had taken place. Changes in throughfall quality in relation to sampling interval have been observed in several studies (e.g. Thimonier, 1998). As the monthly throughfall volumes were similar regardless of collection period length, processes other than evaporation loss (concentration effect) must have been impacting solute concentrations. The washing-off of fine particles collecting on the funnel walls between rainfall events may be the source of the additional mineral elements and neutralisation in samples collected over a longer collection period. While nitrogen transformation processes could explain the changes in inorganic $\mathrm{N}$ concentrations, they could not explain the increase in total $\mathrm{N}$ and DOC loads we observed. Contamination from bird droppings or leaching litter falling into the collectors and resting on the mesh screens between collection times may be the source of the increase in both mineral and organic solutes in samples of longer collection time (Ukonmaanaho and Starr, 2001).

As indicated above, the differences between the sample collection periods were not significant $(p>$ $0.05)$. This would indicate that monthly sampling
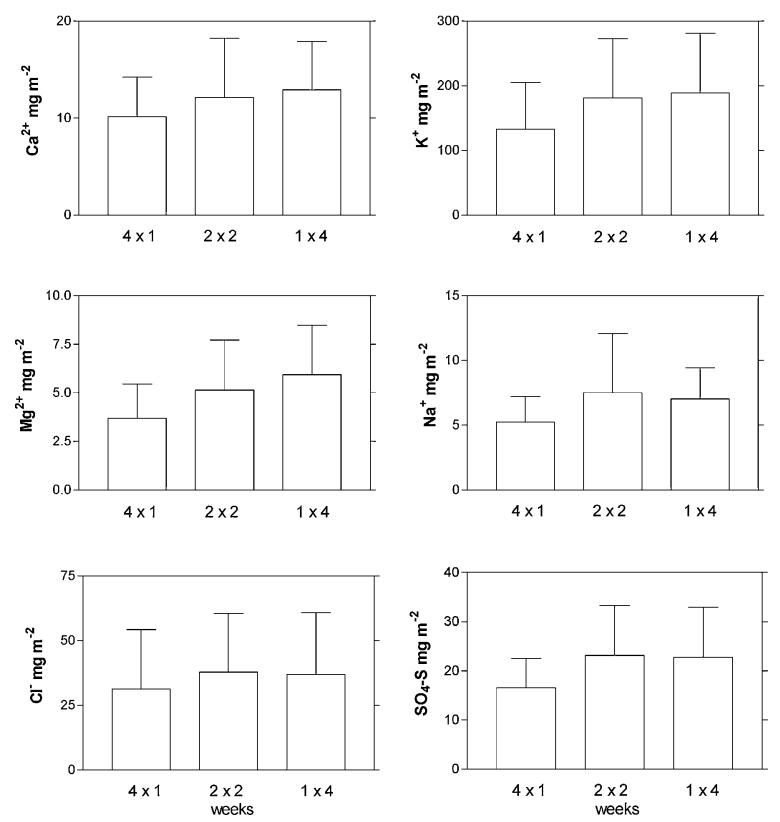

of 2 fortnightly values, $1 \times 4=$ after 4 weeks) at the Norway spruce stand, Finland 
periods could yield as reliable throughfall data as using shorter sampling periods, but with considerably less effort. Although we had expected to observe increasing evaporation losses and consequently increases in solute concentrations with increasing length of the collection period, this was not the case. It was exceptionally wet during the entire study period and this may have minimized evaporation losses. Evaporation and resulting concentration of solutes may occur in years of more normal rainfall and for sites with high potential evaporation losses during the summer.

\subsection{Accuracy and precision: number of collectors required}

The numbers of collectors needed for the mean deposition load to be within 5\%,10\% and $20 \%$ of the true mean with a $95 \%$ certainty for each solute and funnel type and trough collector are presented in Table 4. The number of collectors required to achieve the above criteria varied between the solutes, with inorganic $\mathrm{N}$ forms requiring the most for all collector types, DOC the fewest for funnel type collectors and $\mathrm{H}^{+}$the fewest for trough-type collectors. For DOC, total N, cations and $\mathrm{Cl}^{-}$ions, more funnel type 2 collectors are needed than the other funnel types to achieve the same level of accuracy and precision.
The greater number of trough-type collectors needed to reach the same level of accuracy as the funnel-type collectors may well be attributed to the more heterogeneous species composition and structure of the black spruce forest compared to the Norway spruce stand rather than any difference in collector type efficiency. Although the number of collectors required to meet defined levels of accuracy and precision depend on rainfall intensity and amount (Chourmouzis, 1995), besides the characteristics of the stand, our results clearly indicate that the number of collectors required to achieve a 5\% level of accuracy are impractical for most monitoring purposes. However, the numbers of collectors required decrease substantially if an accuracy of $10 \%$ is deemed acceptable, and even fewer are needed when an accuracy of $20 \%$ is acceptable.

In the ICP Forests programme (ICP Forests Manual, 1998), 10-15 collectors per stand $(50 \times 50 \mathrm{~m}$ plot $)$ are considered necessary to "adequately capture the variability likely to be encountered in throughfall parameters." From Table 4 it can be seen that if 15 funnel collectors had been used in the Norway spruce stand, weekly mean values for throughfall amount and deposition loads of most solutes would have been within $20 \%$ of the true mean with a precision of $95 \%$, but not for inoganic forms of $\mathrm{N}$, except for inorganic $\mathrm{N}, \mathrm{Mg}^{2+}$ and $\mathrm{SO}_{4}{ }^{2-}-\mathrm{S}$. That is, at least a $20 \%$ change in the mean

Table 4 Number of collectors required for mean to be within $\pm 5 \%, \pm 10 \%$ and $\pm 20 \%$ of the true mean (accuracy) with a confidence level of $95 \%$ at the Norway spruce stand (Funnel types 1-4) and at the black spruce stand (trough)

\begin{tabular}{|c|c|c|c|c|c|c|c|c|c|c|c|c|c|}
\hline Parameter & $\begin{array}{l}\text { Level of } \\
\text { accuracy }( \pm \% \\
\text { of true mean) }\end{array}$ & $\mathrm{mm}$ & $\mathrm{H}^{+}$ & DOC & $\mathrm{N}_{\text {total }}$ & $\mathrm{NH}_{4}{ }^{+}-\mathrm{N}$ & $\mathrm{NO}_{3}{ }^{-}-\mathrm{N}$ & $\mathrm{Ca}^{2+}$ & $\mathrm{Mg}^{2+}$ & $\mathrm{K}^{+}$ & $\mathrm{Na}^{+}$ & $\mathrm{Cl}^{-}$ & $\mathrm{SO}_{4}{ }^{2-}-\mathrm{S}$ \\
\hline \multirow[t]{3}{*}{ Funnel 1} & 5 & 85 & 171 & 28 & 76 & 416 & 400 & 195 & 251 & 51 & 233 & 128 & 312 \\
\hline & 10 & 21 & 43 & 7 & 19 & 104 & 100 & 49 & 63 & 13 & 58 & 32 & 78 \\
\hline & 20 & 5 & 11 & 2 & 5 & 26 & 25 & 12 & 16 & 3 & 15 & 8 & 19 \\
\hline \multirow[t]{3}{*}{ Funnel 2} & 5 & 52 & 118 & 38 & 93 & 399 & 351 & 246 & 373 & 102 & 246 & 183 & 521 \\
\hline & 10 & 13 & 30 & 9 & 23 & 100 & 88 & 61 & 93 & 25 & 61 & 46 & 130 \\
\hline & 20 & 3 & 7 & 2 & 6 & 25 & 22 & 15 & 23 & 6 & 15 & 11 & 33 \\
\hline \multirow[t]{3}{*}{ Funnel 3} & 5 & 55 & 149 & 31 & 92 & 383 & 438 & 195 & 291 & 78 & 224 & 151 & 480 \\
\hline & 10 & 14 & 37 & 8 & 23 & 96 & 109 & 49 & 73 & 20 & 56 & 38 & 120 \\
\hline & 20 & 3 & 9 & 2 & 6 & 24 & 27 & 12 & 18 & 5 & 14 & 9 & 30 \\
\hline \multirow[t]{3}{*}{ Funnel 4} & 5 & 76 & 139 & 26 & 65 & 367 & 437 & 212 & 251 & 44 & 212 & 126 & 277 \\
\hline & 10 & 19 & 35 & 6 & 16 & 92 & 109 & 53 & 73 & 11 & 53 & 31 & 69 \\
\hline & 20 & 5 & 9 & 2 & 4 & 23 & 27 & 13 & 18 & 3 & 13 & 8 & 17 \\
\hline \multirow[t]{3}{*}{ Trough } & 5 & 233 & 93 & 229 & 213 & 4919 & 470 & 448 & 1371 & 274 & n.d & 110 & 180 \\
\hline & 10 & 58 & 23 & 57 & 53 & 1230 & 118 & 112 & 343 & 68 & n.d. & 27 & 45 \\
\hline & 20 & 15 & 6 & 14 & 13 & 307 & 29 & 28 & 86 & 17 & n.d & 7 & 11 \\
\hline
\end{tabular}

Values are mean values of the each sampling period for each stand. Parameters requiring $\leq 15$ collectors are in bold. 
Table 5 Mean (coefficient of variation \% in parentheses) throughfall amount $(\mathrm{mm})$ and concentration of elements in throughfall collected from different spatial arrangements of collectors (see Figs. 2 and 3)

\begin{tabular}{|c|c|c|c|c|c|c|c|}
\hline \multirow[b]{3}{*}{ Parameter } & \multicolumn{7}{|c|}{ Arrangement of collectors } \\
\hline & \multicolumn{5}{|c|}{ Kasiniemi, Finland } & \multicolumn{2}{|c|}{ ELRA, Canada } \\
\hline & Block $10 \mathrm{~m} \times 10 \mathrm{~m}$ & Block $20 \mathrm{~m} \times 20 \mathrm{~m}$ & Square & Row & Random & Systematic & Random \\
\hline $\mathrm{mm}$ & $12(75)$ & $12(72)$ & $12(72)$ & $12(72)$ & $12(69)$ & $19(76)$ & $29(56)$ \\
\hline $\mathrm{H}^{+}$ & $6.30(162)$ & $7.30(155)$ & $7.58(152)$ & $7.13(160)$ & $8.36(172)$ & $26.16(122)$ & $30.67(102)$ \\
\hline DOC & $19.81(40)$ & $20.03(47)$ & $19.78(55)$ & $18.26(43)$ & $19.48(60)$ & $14.17 *(26)$ & $9.84^{*}(15)$ \\
\hline $\mathrm{N}_{\text {total }}$ & $1.16(35)$ & $1.20(49)$ & $1.19(49)$ & $1.14(39)$ & $1.18(39)$ & $1.26(42)$ & $0.84(31)$ \\
\hline $\mathrm{NH}_{4}{ }^{+}-\mathrm{N}$ & $0.49(71)$ & $0.41(73)$ & $0.42(77)$ & $0.48(75)$ & $0.48(68)$ & $0.10(122)$ & $0.09(83)$ \\
\hline $\mathrm{NO}_{3}{ }^{-}-\mathrm{N}$ & $0.58(131)$ & $0.57(137)$ & $0.58(131)$ & 0.59 (129) & $0.58(138)$ & $0.14(51)$ & $0.17(83)$ \\
\hline $\mathrm{Ca}^{2+}$ & $0.50(47)$ & $0.48(48)$ & $0.49(53)$ & $0.44(44)$ & $0.46(55)$ & $0.73(36)$ & $0.51(14)$ \\
\hline $\mathrm{Mg}^{2+}$ & $0.19(49)$ & $0.19(48)$ & $0.19(56)$ & $0.17(46)$ & $0.18(57)$ & $0.07(43)$ & $0.06(26)$ \\
\hline $\mathrm{K}^{+}$ & $5.35(50)$ & $5.05(47)$ & $5.06(55)$ & $4.73(46)$ & $4.95(50)$ & $1.29(42)$ & $0.93(38)$ \\
\hline $\mathrm{Na}^{+}$ & $0.25(34)$ & $0.24(36)$ & $0.24(44)$ & $0.23(34)$ & $0.24(48)$ & n.d. & n.d. \\
\hline $\mathrm{Cl}^{-}$ & $1.32(66)$ & $1.27(64)$ & $1.30(73)$ & $1.19(60)$ & $1.26(68)$ & $1.77(50)$ & $1.62(48)$ \\
\hline $\mathrm{SO}_{4}{ }^{2-}-\mathrm{S}$ & $2.24(58)$ & $2.22(57)$ & $2.22(61)$ & $2.11(58)$ & $2.18(61)$ & $0.73(42)$ & $0.82(34)$ \\
\hline
\end{tabular}

Concentrations are in $\mathrm{mg} \mathrm{l}^{-1}$, except for $\mathrm{H}^{+}$ions, which are in $\mu \mathrm{mol} \mathrm{l}^{-1}$.

*Concentrations significantly different $p<0.05$.

n.d.; Not determined.

value for most parameters would be required before they could be considered to be statistically different. For the black spruce stand, it would be possible to detect a change with such accuracy using the 15 trough collectors for all parameters except inorganic forms of $\mathrm{N}, \mathrm{Ca}^{2+}, \mathrm{K}^{+}$and $\mathrm{Mg}^{2+}$ ions.

\subsection{Effect of spatial arrangement of collectors}

The amount and quality of throughfall in relation to the layout arrangement of the funnel and trough collectors in the two study stands are presented in Table 5. Although the effect of spacing and placement of collectors on throughfall measurements has been acknowledged (Thimonier, 1998), there appears to have been no systematic study of such effects. In placing throughfall collectors, random or systematic placing or a combination of both is recommended in the ICP Forests Manual (1998), but without any evidence. In stands where there is no systematic pattern in the distribution of trees, such as in our study, systematic or random placement of throughfall collectors can be expected to have no effect on throughfall measurements at the stand scale. However, systematic placement should perhaps be avoided in plantation forests or managed stands that show systematic stem spacing because of the risk of coincidence with the collector spacing and placement.
At both stands, the spatial arrangement of collectors (12 in the case of the Norway spruce stand and 15 in the case of the black spruce stand) had no significant $(p>0.05)$ effect on the amount of throughfall or solute concentrations, with the exception of DOC at the black spruce stand. The coefficients of variation (cv) for the Finnish site indicated that variation was generally less with the systematic layout, with the row arrangements having the lowest cv for six of the 12 parameters, compared to the random layout. In contrast, at the black spruce stand, variation with the random layout compared to the systematic layout of troughs was less for 10 out of the 11 parameters studied. Across all arrangements, base cation concentrations tended to show the least variation and concentrations of $\mathrm{H}^{+}$ions and inorganic $\mathrm{N}$ the most variation.

\section{Conclusions}

We evaluated the relative performance of various funnel-type and trough-type throughfall collectors in two different forest stands (a Norway spruce and a black spruce) with respect to their ability to accurately estimate throughfall deposition loads. The data were evaluated with respect to funnel diameter and presence or absence of a rim, number of collectors required to reach defined levels of accuracy and precision, duration 
of sampling period, and the spacing and arrangement of the collectors.

At the Norway spruce stand we found that throughfall and open precipitation deposition loads varied significantly with the funnel type used. The presence of a rim around the funnel resulted in significantly greater throughfall deposition loads even though throughfall volumes were unaffected. We attributed this to increased efficiency of dry deposition and litterfall retention; this material being less easily blown out of collectors with a rim. The presence of a rim had no significant effect on either open precipitation amounts or solute loads.

Funnel diameter had a significant effect on precipitation and throughfall volumes and solute loads. Increased open precipitation amount and solute loads with decreasing funnel size were attributed to wind and splash errors rather than wetting loss errors, as open precipitation solute concentrations were unaffected by funnel size. The observed increase in throughfall solute loads with decreasing funnel size are unlikely to be related to wind, splash or wetting loss errors but rather to the efficiency with which dry deposition and litterfall was entrapped, with the smaller sized funnels being more efficient.

Although our data did not allow for reliable statistical testing, increasing the length of the collection period (1 week, 2 weeks, and 4 weeks) appeared to increase calculated monthly throughfall loads, Shorter collection periods are therefore to be considered preferable.

Calculations indicated that 15 collectors at the Norway spruce stand would be sufficient for eight out of the twelve studied parameters to be determined to within $20 \%$ of the true mean weekly value with a confidence level of $95 \%$. However, at the black spruce stand, which had a more varied structure, the same level of confidence was only achieved for five out of the eleven studied parameters. The greatest number of collectors is needed for inorganic $\mathrm{N}$.

Using either a systematic or random design for placement of throughfall collectors gave similar results in our study stands. However, systematic placement should perhaps be avoided in plantation forests or in managed stands that show systematic stem spacing.

Acknowledgements We would like to thank the following persons for assistance carrying out in this study; in Finland: Kauko Taimi, Pekka Helminen, Tapio Huttunen, Markku Pastila, Pentti Häkkilä, Riitta Heinonen, Tuija Hytönen and Anneli Supponen, and in Canada: Andrew Sutton, Mike White, Mike Pinkney, Francis McCoubrey, Kaeli Stark and Leslie Proctor. This study was partly funded by the EU (Council Regulation (EEC) No 3528/86, Pilot Study Project No. 97.60.SF003.0) and grants from the Academy of Finland and the Sustainable Forest Management Network (SFMN), Canada.

\section{References}

Bleeker, A., Draaijers, G., van der Veen, D., Erisman, J.W., Möls, H., Fonteijn, P., \& Geusebroek, M. (2003). Field intercomparison of throughfall measurements performed within the framework of the Pan European intensive monitoring program of EU/ICP Forest. Environmental Pollution, 125, 123138.

Bredemeier, M. (1988). Forest canopy transformations of atmospheric deposition. Water Air and Soil Pollution, 40, 121138.

Cole, D.W., \& Rapp, M. (1981). Elemental cycling in forest ecosystems. In: D.E. Reichle, (ed.), Dynamic Properties of Forest Ecosystems. Cambridge University Press, International Biological Programme, 23, 341409.

Cajander, A.K. (1949). Forest types and their significance. Acta Forestalia Fennica, 56, 1-71.

Chourmouzis, C. (1995). The partitioning of rainwater in $26 \pm$ 27 year-old, plantation grown, red, white and black spruce (p. 178). M.Sc. Thesis. Guelph, Ontario: University of Guelph.

Dingman, S.L. (2002). Physical hydrology (p. 646). New Jersey: Prentice Hall.

Draaijers, G.P.J., Erisman, J.W., Spranger, T., \& Wyers, G.P. (1996). The application of throughfall measurements for atmospheric deposition monitoring. Atmospheric Environment, 30, 3349-3361.

Drebs, A., Nordlund, A., Karlsson, P., Helminen, J., \& Rissanen, P. (2002). Climatological statistics of Finland 1971-2000. Helsinki: Finnish Meteorological Institute.

Environment Canada (2004). National Climate Data and Information Archive, www.msc.ec.gc.ca/climate/climate normals/

Erisman, J.W., Möls, H., Fonteij, P., Geusebroek, M., Draaijers, G., Bleeker, A., \& Van der Veen, D. (2003). Field intercomparision of precipitation measurements performed within the framework of the Pan European Intensive Monitoring Program of EU/ICP Forest. Environmental Pollution, 125, 139-155.

Finnish Statistical Yearbook of Forestry (2003). (ed A. Peltola). Finnish Forest Research Institute, p. 388.

Førland, E.J., Allerup, P., Dahlström, B., Elomaa, E., Jónsson, T., Madsen, H., Perälä, J., Rissanen, P., Vedin, H., \& Vejen, F. (1996). Klima. Manual for operational correction of Nordic precipitation data (P. 66). Norwegian Meteorological Institute.

Gordon, A.M., Chourmouzis, C., \& Gordon A. G. (2000). Nutrient inputs in litterfall and rainwater fluxes in 27-year old red, black and white spruce plantations in central Ontario, Canada. Forest Ecology and Management, 138, 65-78. 
Hyvärinen, A. (1990). Deposition on forest soils - effect of tree canopy on throughfall. In: Kauppi, P., Anttila, P., \& Kenttämies, K., (eds.), Acidification in Finland (pp. 199213). Berlin: Springer-Verlag.

ICP Forests Manual. (1998). Part VI, Measurement of Deposition. In: Manual on Methods and Criteria for Harmonized Sampling, Assessment, Monitoring and Analysis of the Effects of Air Pollution on Forests, (4th Edn.), United Nations Economic Comission for Europe Convention on Long-Range Transboundary Air Pollution. International Co-Operative Programme on Assessment and Monitoring of Air Pollution Effects on Forests.

Jones, R.K., Pierpoint, G., Wickware, G.M., Jeglum, J.K., Arnup, R.W., \& Bowles, J.M. (1983). Field guide to forest ecosystem classification for the clay belt the Ontario ministry of natural resources (P. 123). Canada: Ontario.

Kimmins, J.P. (2004). Forest Ecology: A foundation for sustainable forest management and environmental ethics in forestry, 3rd edn. (P. 631) N-Y.: Prentice-Hall.

Kostelnik, K.M., Lynch, J.A., Grimm, J.W., \& Corbett, E.S. (1989). Sample size requirements for estimation of throughfall chemistry beneath a mixed hardwood forest. Journal of Environmental Quality, 18, 274-280.

Lindroos, A.-J., Derome, J., Derome, K., \& Niska, K. (1999). Deposition. In: Raitio, H., \& Kilponen, T. (eds.), Forest condition monitoring in Finland, national report 1998. Finnish Forest Research Institute. Research Papers, 743, $72-77$.

Mahendrappa, M.K., \& Kingston, D.G.O. (1982). Prediction of throughfall qunatities under different forest stands. Canadian Journal of Forest Reserch, 12, 474-481.

Mikola, P. (1982). Application of vegetation science to forestry in Finland. In: Jahn, G. (ed.), Handb. Vegetat. Sci., 12, 199224.
Morris, D., Gordon, A.G., \& Gordon, A.M. (2003). Patterns of canopy interception and throughfall along a topographic sequence for black spruce dominated forest ecosystems in northwestern Ontario. Canadian Journal of Forest Reserch, 33, 1046-1060.

Parker, G.G. (1983). Throughfall and stemflow in the forest nutrient cycle. Advances in Ecological Reserch, 13, 58-133.

Piirainen, S., Finér, L., \& Starr, M. (1998), Canopy and soil retention of nitrogen deposition in a mixed boreal forest in eastern Finland, Water Air and Soil Pollution, 105, 165-174.

Puckett, L.J. (1991). Spatial variability and collector requirements for samplng throughfall volume and chemistry under a mixed-hardwood canopy. Canadian Journal of Forest Research, 21, 1581-1588.

Reynolds, B., \& Neal, C. (1991). Trough versus funnel collectors for measuring throughfall volumes. Journal of Environmental Quality, 20, 518-521.

Tukey, H. (1970). The leaching of substances from plants, Annual Review of Plant Physiology and Molekylar, 21, 301-321.

Thimonier, A. (1998). Measurement of atmospheric deposition under forest canopies: some recommendations for equipment and sampling design, Environmental Monitoring and Assessment, 52, 353-387.

Ukonmaanaho, L.,\& Starr, M. (1995). Throughfall and stemflow. In: Bergström, I., Mäkelä, K., \& Starr M., (eds.). Integrated Monitoring Programme in Finland. First National Report. Ministry of the Environment, Environmental Policy Department, Report 1/1995, pp. 35-36.

Ukonmaanaho, L., \& Starr, M. (2001). The importance of leaching from litter collected in litterfall traps. Environmental Monitering and Assessment, 66, 129-146.

Ukonmaanaho, L., \& Starr, M. (2002). Major nutrients and acidity: budgets and trends at four remote boreal stands in Finland during the 1990s. The Science of Total Environment, 297, 21-41. 